Research article

DOI: $10.22363 / 2313-1683-2019-16-1-88-100$

UDC 378.016

\title{
Analysis of the English Language Needs of Students at the Russian Technological University
}

\author{
Olga G. Rossikhina, Polina V. Ermakova, Olga A. Aleshchenko \\ National University of Science and Technology MISiS \\ 4 Lenin Ave., Moscow, 119049, Russian Federation
}

\begin{abstract}
The article looks into the English language needs of engineering students and young graduates at one of the leading technological universities in Russia - NUST MISiS. The authors used a mixed methodology approach to explore how often and in what real-life situations current and former students use the English language. 107 paper questionnaires were completed by master's degree students in class and the answers were counted; 123 responses were received online from 2015 and 2016 graduates and processed statistically; 17 structured interviews with college administrators and subject professors were recorded and then coded for the main categories. The results demonstrate that despite dramatic changes at NUST MISiS under The Competitiveness Enhancement Program 5-100, good English competence is not a priority, with the majority of young graduates being 'unsure' about its benefits for their career and some administrators calling it 'the least required competence'. However, the English language needs vary across subject departments. Thus, students majoring in new materials and programming use English on a regular basis, while economists and metallurgists might not really need it in both studies and future job. Overall, the most required skill is reading, and the least used ones are oral communication and academic writing in English. The authors discuss how orientation on potential rather than actual needs can affect the ESP/EAP course design in the context of engineering education in Russia.
\end{abstract}

Keywords: needs analysis, English, engineering students, employment, questionnaires, structured interviews

\section{Introduction}

The English language curriculum in higher educational institutions worldwide is designed with a particular purpose, which is to prepare students for operating successfully in academic and professional contexts. In the majority of universities the English course comprises the English for Academic Purposes (EAP) or English for Specific Purposes (ESP) components or rather a combination of both. Needs analysis plays a vital role in the design of the EAP/ESP course (Hutchinson \& Waters, 1997; Jordan, 1997).

(C) Rossikhina O.G., Ermakova P.V., Aleshchenko O.A., 2019

This work is licensed under a Creative Commons Attribution 4.0 International License 
Needs analysis involves identifying the level to achieve, language to learn, communication situations for language use and study skills needed in the target situation as well as the analysis of their current development and the gap in skills to be bridged (Serafini et al., 2015).

There are many publications (for example, those reviewed by Braine (2002), or a more recent study by Dooey (2010)) on the design of pre-sessional and in-sessional EAP courses in English-medium university based on elaborate analysis of needs of non-native speakers of English. The workplace needs of engineers in the countries where English is widely spoken and how university programmes meet industry demands have also received a lot of attention (Darling \& Dannels, 2003; Huhta et al., 2013; Kassim \& Ali, 2013; Sageev \& Romanowsky, 2001; Prior, 2014).

In Russia the situation is different as the overwhelming majority of universities remain Russian-language medium institutions, where the needs in English are not explicit. Sociologists demonstrate quite low levels of foreign language proficiency even among young generation or people with higher education degrees (e.g Levada Center survey, 2014). Recruiters in Russia also seem to put low priority to foreign language competence (Sostoyanie rossiyskogo rynka truda, 2018).

However, Russian educators are convinced that a good command of English is important for 'success in life' (Gotlib, 2009) or 'building professional career' (Aref'ev, 2008; Gotlib, 2009; Levchenko et al., 2016) or 'improving academic mobility' (Polenova \& Pshegusova, 2015). As there is minimal evidence to support these claims, tertiary institutions often operate perceived rather than real-life needs of their learners. In the British Council Baseline Study Frumina and West (2015, p. 45) described this situation as 'surprisingly little attention was paid to students' needs, beyond noting that the majority of students felt that English was important or very important for their careers'. As a result of this lack of factual data, the syllabus of an EAP/ESP course in a Russian university is usually based on general and often theoretical understanding of students' current and future use of English in their academic and professional lives.

The State educational standards for higher education claim that the general competence for all engineering majors is the ability 'to communicate orally and in writing in Russian and a foreign language in situations of interpersonal and intercultural interaction' for bachelors and 'readiness to communicate in L1 and L2 in the professional context, presenting clear and reasoned opinions and conclusion' (State Educational Standards for 2016-2018). Unfortunately, there is very little factual evidence of how engineering graduates in Russia meet these requirements.

At the same time, the situation with Russian higher education has changed dramatically since 2012, when the baseline study was conducted. Many universities are undergoing the process of internalization, which means integration of national educational system into the world scientific and academic space.

NUST MISiS (the National University of Science and Technology) is at the forefront of this process, being the winner in the Competitiveness Enhancement Program 5-100. This governmental project for boosting competitiveness of Russian universities in the world high education market triggered drastic changes into the scientific, research, educational and extracurricular activities. Unlike the majority of technical institutions in Russia, NUST MISiS can boast an extensive English language course for all bachelor's 
degree students throughout all four years of their studies. However, it still remains a nonEnglish medium institution in a non-English language country, where the language of instruction in all university courses except international master's programmes is still Russian, and the need in English is not obvious.

Taking this leading technical university as a model, we looked into the actual English language needs of engineering students in Russia. As there is no reliable evidence that NUST MISiS students and alumni really use English outside the English class, let alone how often and in what real-life situations they do it, this paper indicates communication situations in the context of academic studies and alumni's employment needs. The data are obtained from different sources by a variety of methods. We assume that these data can inform the ESP/EAP course design in many similar institutions and make it more relevant to learners' actual needs.

\section{Methodology}

\section{Background}

NUST MISiS is a vivid example of Russian higher education modernization process, being one of the 21 university participants (www.5top100.ru/en/universities), whose strategic goal is to become world leader in fundamental and applied research in materials science, metallurgy, mining, nanotechnologies, and significantly improve its current standings in IT and biomedicine. The Russian language remains the only language of instruction in all undergraduate disciplines with a few English medium master's programmes launched recently.

However, recognizing the role of English in global communication, in 2010 NUST MISiS launched a specially-conceived English language curriculum for all undergraduates regardless their major (National University of Science and Technology, 2018). Unlike language programmes in the majority of technical universities in our country, this course is long-term and intensive, with many contact and online hours. Another feature of the programme is its external final assessment in the form of IELTS exam.

The 4-year programme comprises General English (GE), EAP and ESP contexts and targets at achieving B2 level of proficiency CEFR by half of graduates. The EAP is taught mainly as IELTS preparation materials, the ESP component currently does not exist as an independent component, but is introduced through project work. The place and role of ESP projects in the curriculum is regularly revised to meet concerns of subject professors. They see the ability to translate technical texts and mastering specific terminology as the key need of their students and believe that only this expertise will enable their students to read research literature extensively and maybe even write articles.

The main scope of the research was conducted in the 2015/2016 academic year, with some findings obtained in 2018. This is important to note because the situation at our university has been changing very fast as it has been rising in international ratings.

\section{Participants and methods}

Data were collected from multiple sources using a variety of qualitative and quantitative methods. This mixed-method approach described in detail in Cowling (2007) and Huhta 
et al. (2013) allows to obtain more objective and thorough information for needs analysis through triangulation of data.

The methods and informants are listed below:

- background information from recruitment websites;

- online surveys of the $1^{\text {st }}-3^{\text {rd }}$ year students;

- online survey of alumni;

- paper questionnaires for postgraduate students;

- semi-structured interviews with domain specialists;

- structured interviews with college administrators and subject professors.

Quantitative data. The Department of Modern Languages (IYAKT) annually conducts two surveys as a monitoring tool. In this article we used the results obtained in 2017/2018. The first survey in the form of paper questionnaires was administered to $1^{\text {st }}$ year students during English classes and 200 responses (about $30 \%$ ) were obtained.

The online survey, which monitored $1^{\text {st }}, 2^{\text {nd }}$ and $3^{\text {rd }}$ year students' satisfaction with the programme, was completed by $14 \%$ of all undergraduates studying in the English programme.

Postgraduate students were used as a source of quantitative data about the academic context. Questionnaires were distributed and completed in class. Multiple choice questions were prompted by CEF Professional Profiles (Huhta et al., 2013) and concerned mainly frequency and situations of English use during under-and postgraduate studies. Students' questionnaires were revised twice after piloting with several master degree students.

Overall, we received and processed 107 responses out of 228 postgraduates enrolled in the course. Their distribution of responses among colleges was the following: 69 were from College of Engineering (CEng), 29 from College of New Materials (CNM) and 9 from College of Economics (CEc). College of IT (CIT) did not have master degree programmes at the time of research. We applied questionnaires before interviews as we had to have some picture before appointing meetings with university authorities and subject professors.

The online survey of 2015 and 2016 graduates on the role of English in their professional lives was conducted in November/December 2018. The questions were prompted by Technical Communication Survey described in Sageev et al. (2001). The questionnaires with 5-level Likert items ranged from 'strongly agree' to 'strongly disagree' were mailed to 1900 alumni, and 123 responses were obtained and analysed.

Qualitative data. Questionnaires completed by master's degree students informed a small number of semi-structured interviews with subject professors and further on a larger series of structured interviews with university academic and administrative staff. The $1^{\text {st }}$ drafts, which originally contained 12 questions, were piloted in semi-formal interviews with professors who the researchers knew well. As a result, the number of questions was reduced to 7 and wording was revised for more clarity. We conducted 17 interviews with 4 heads of colleges, 6 heads of specialist departments and 7 subject professors. All interviews, which lasted from 30 to 50 minutes, were recorded and then transcribed by the research team. Then they were coded and the main categories developed (Bell \& Bryman, 2003).

Job descriptions and requirements for candidates for engineering positions in Russia were retrieved from Russian job hunting websites (www.rabota.ru; www.headhunting.ru and www. superjob.ru) in 2018. 


\section{Results}

\section{Motivation}

The $1^{\text {st }}$ year students were asked to answer two questions:

1. Did you know about the intensive English language programme at NUST MISiS at the point of admission?

2. Did this information affect your decision to enter this university?

The results for all four colleges are presented in Figure.

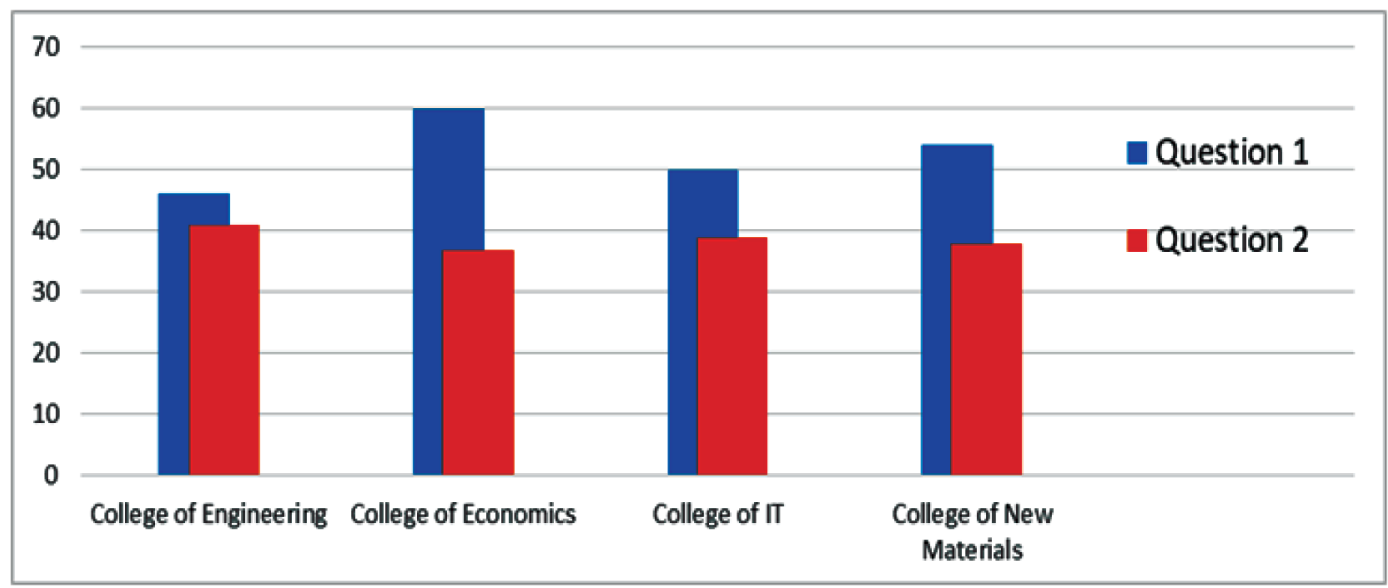

Figure. Awareness of the programme in 2017

The percentage of those aware of the programme varied from 46 to 60 across colleges, and only for $37-41 \%$ this information affected their choice Thus, quite predictably, entrants are mostly unaware of their English language needs and rely on the university and language department authorities to set the goals and design the language course for them.

Passing IELTS successfully motivates $65 \%$ of $1^{\text {st }}, 2^{\text {nd }}$ and $3^{\text {rd }}$ year students, with $35 \%$ either indifferent or not motivated.

The $1^{\text {st }}, 2^{\text {nd }}$ and $3^{\text {rd }}$ year-students participated in an online survey, where they were asked if passing IELTS successfully motivated them to study English. The majority of respondents $(65 \%)$ answered positively but the proportion of those who are not motivated or unsure was quite high $(35 \%)$.

\section{Communication situations in the academic context}

Most postgraduates wrote in questionnaires that they used English only occasionally outside English classes in both bachelor and master's degree courses (51 and $47 \%$ accordingly). Far fewer respondents admitted that they needed English almost every day in their bachelor studies $(11 \%)$ or use it that often in their master degree course $(28 \%)$. A minor proportion of students from both tiers (10\%) never used English in their studies.

A list of communication situations and the percentage of students who opted for each of them are given in Table 1. As can be seen in Table 1, the most common activity is reading online materials and articles. The second most required usage of English is 
listening to lectures and writing short pieces like student conference abstracts or business letters.

Table 1

Communication situations in academic context

\begin{tabular}{lcc}
\hline \multicolumn{1}{c}{ Communication situations } & Bachelor degree, \% & Master degree, \% \\
\hline Listening to lectures & 41 & 42 \\
Informal communication with guest researchers in the laboratory & 26 & 24 \\
Conference talks & 31 & 5 \\
Poster presentations & 9 & 6 \\
Reading articles & 53 & 40 \\
Working with computer programmes & 8 & 26 \\
Reading online materials & 67 & 67 \\
Writing conference abstracts & 39 & 25 \\
Writing research papers & 2 & 1 \\
Writing letters, e.g. CV & 34 & 63 \\
Writing course papers & Single initiative & Some programmes \\
Writing dissertations & None & Single initiatives \\
\hline
\end{tabular}

${ }^{1}$ Students' conferences only

Practically no course papers or diplomas are written in English by bachelor's degree students. As far as master's dissertations are concerned, English is the language for writing only in international postgraduate programmes. Only a few students had taken part in academic mobility programmes, and among countries named in questionnaires were non-English speaking countries, such as Germany, France, Poland and Czech Republic.

The quantitative data were supplemented by qualitative information obtained through semi-structured and structured interviews. According to some professors, 'English is the least demanded competence at the university as there is no English-speaking environment. Content professors generally do not know English well enough to give lectures or communicate in the language'. Bachelor degree students hardly ever use English in their studies, but postgraduate and PhD students encounter it much more often.

On the other hand, many administrators and professors admit that the situation is changing gradually with the increasing number of international contacts inside and outside university under Project 5-100. Domain specialists acknowledge the fact that they can currently see advanced students who give talks in English and understand fluent speech. Some professors even take it further saying that 'they can read and write in English better than me'.

The main findings from the interviews with domain specialists are given in Table 2. As the table illustrates, the major area for English use in both tiers remains reading online sources, research papers and working with computer programmes. Practically no course papers, diplomas or master's dissertations are written in English except for single initiatives of two specialist departments. Discipline departments do not make any formal claims concerning English-language sources used in graduation papers, but there are some 'recommendations' to cite 1-2 for bachelor diplomas and at least 5 for master dissertations. Listening to guest lecturers, though optional, is becoming part of university routine, as well as oral communication with visiting students and research or maintenance staff. Public speaking is mainly limited to making occasional poster presentations and answering 
questions. The most neglected skill is writing, commonly limited to writing abstracts. Writing research papers in both languages is the prerogative of scientific supervisors, not students. Academic mobility seems to be a rare occasion and it is usually summer schools or short internship programmes in non-English speaking countries.

Table 2

Snapshot of skills exercised in English at different tiers of education

\begin{tabular}{|c|c|c|c|}
\hline Tier & Reading & Listening and speaking & Writing \\
\hline Bachelor degree & $\begin{array}{l}\text { There are no formal } \\
\text { requirements to the number } \\
\text { of sources in the bibliography } \\
\text { to a graduation paper, but } \\
\text { recommended number is } 1 \\
\text { or } 2 \text {. Articles are selected by } \\
\text { scientific supervisors. }\end{array}$ & $\begin{array}{l}\text { Students listen to guest lecturers } \\
\text { occasionally, but these lectures } \\
\text { are usually not compulsory. } \\
\text { A small proportion participate in } \\
\text { internship in foreign companies } \\
\text { in Moscow or summer schools in } \\
\text { non-English speaking countries. } \\
\text { Talks and presentations at in- } \\
\text { house students' conferences are } \\
\text { very common. }\end{array}$ & $\begin{array}{l}\text { A b s t r a c t f o r } \\
\text { students'conferences is } \\
\text { the most common genre. } \\
\text { Writing skills beyond } \\
\text { mastering Google Translate } \\
\text { are not needed. }\end{array}$ \\
\hline Master degree & $\begin{array}{l}\text { Recommended number of } \\
\text { sources is from } 5 \text { to } 10 . \\
\text { Students start reading } \\
\text { authentic English articles } \\
\text { and use English-medium } \\
\text { computer programmes. }\end{array}$ & $\begin{array}{l}\text { Students listen to some lectures } \\
\text { and communicate with visiting } \\
\text { research staff. Single students } \\
\text { join master programmes abroad } \\
\text { or make poster presentations at } \\
\text { international conferences. }\end{array}$ & $\begin{array}{l}\text { Abstracts for conference } \\
\text { talks remain the most } \\
\text { popular genre. There can } \\
\text { be single course papers or } \\
\text { even dissertations, but } \\
\text { English in these papers is } \\
\text { not assessed. }\end{array}$ \\
\hline
\end{tabular}

According to the interviews, there are great differences in language needs across departments. Thus, students of economics and management can easily survive professionally without a foreign language as all literature in the economy of domestic industrial plants is published in Russian, and the majority of computer programmes are translated into Russian as well. Those students who are already involved in research, for example, students from CNM studying semiconductors or new materials, have to read professional literature in English to be aware of the current situation in their field, though they do not read widely and two or three articles seem sufficient. Students of CIT and CNM also sometimes use computer programmes and instructions which exist only in English.

The immediate needs are also changing as students advance in their studies. Table 2 demonstrates progression of target needs from almost non-existent during the first years of studies to a strong need for students involved in research in near-graduation and postgraduation years. Unfortunately, due to objective reasons, English curriculum unfolds in a backward direction. In junior years students have many English classes, but at this time learners are outside any professional context. In the $4^{\text {th }}$ year, when they start working in their discipline departments, their English course comes to the end. In senior years, i.e. in postgraduate and doctoral programmes, the number of hours is very limited and may not provide much support to learners.

\section{Employment needs}

Job descriptions and requirements for candidates for engineering positions in Russia obtained from three job hunting websites brought the following information.

Out of 72 positions the English language was mentioned only in 12 (17\%), and almost all employers from these $17 \%$ asked for candidates with 'technical English' or 'ability to 
read/work with technical documents' or 'technical English is a plus'. The essential requirements included strong specialist knowledge, relevant qualifications and experience and personal qualities such as self-discipline or result-orientation, not high command of English.

Interviews with domain specialists enabled us to get some understanding of the employment sector for the university alumni. The interviewers were first asked to give a rough estimation of the proportion of their graduates who do or do not have a job related to their major. The consensus opinion was that currently about $80-90 \%$ of alumni practice their profession, and these figures did not vary much across disciplines.

The second question concerned the place of work, namely the laboratory, the manufacturing plant, the office or the educational institution. Obviously, the places of work and responsibilities are different for four colleges.

Graduates from CIT are more likely to find employment with foreign companies or even abroad, but at the same time FSB and similar structures offer many employment opportunities. English language is needed in both scenarios.

Graduates from CEng work in a plant, laboratory and office in almost equal proportions. Laboratory work involves applied engineering research, closely linked with production.

CNM graduates researchers, so laboratory context predominates over industry and office work. Alumni from CEc find employment in banks, insurance companies and offices of metallurgical companies, and they are never involved in production or research. Educational sector is also not uncommon for economists and managers.

Despite domain-related differences, the consensus view was that the majority of graduates are not going to use English at all as they will be working either in the militaryindustrial complex, where information is classified, or in Russian financial institutions $(\mathrm{CEc})$. Some will go home to CIS countries to work in industry and they will unlikely to use English there:

'Our students are not going to need English unless they find a position abroad or with an international employer. But these are rare occasions' (CNM).

'In our domain almost all printed and internet resources are in Russian' (CEc).

However, a small proportion of alumni who will follow the science path, have different needs:

'English is the language of science because all topical publications are in this language. About $10 \%$ of our students work in science, and they cannot be successful in the profession without English' (CNM).

This qualitative information was supplemented with quantitative data obtained from online questionnaires completed by NUST MISiS alumni who graduated in 2015 and 2016. There were three questions (Table 3 ) with 5 variants of answers: strongly agree (5), agree (4), do not agree or disagree (3), disagree (2) and strongly disagree (1).

Table 3

The impact of command of English on alumni's jobs

\begin{tabular}{clcc}
\hline$\#$ & \multicolumn{1}{c}{ Question } & Mean & Median \\
\hline 1 & Command of the English language helped me get a job & 2.97 & 3.0 \\
2 & $\begin{array}{l}\text { Knowledge and experience I received in English classes help } \\
\text { me in my job }\end{array}$ & 3.42 & 4.0 \\
3 & Command of the English language helps me in career advance & 3.17 & 3.0 \\
\hline
\end{tabular}


The statistical results can be interpreted as uncertain needs for many respondents. The majority of alumni are unsure about the benefits of good command of English, though they do not deny its positive impact on their job in general (question 2 gets the highest score). As all respondents had no more than three years of service, their career advancement was not an issue yet. However, for many graduates knowledge of English was their employment advantage (mean 2.97).

\section{Discussion}

The results demonstrate that the English language needs of undergraduate and postgraduate students even at a leading technical university in Russia are often limited and cannot be clearly defined as an average NUST MISiS student can graduate from the university having hardly ever used English in their subject disciplines. These findings do not comply with the requirements for foreign language competence specified in State Educational Standard (www.fgos.ru) and common belief that Russian students see English proficiency as an essential attribute of successful career (Arefev, 2008; Gotlib, 2009; Levchenko et al., 2016), but they agree with the research made by Frumina and West (2012) and Frumin and Dobryakova (2012). The authors claimed that 'students in Russian institutions of higher education are rarely required to use English in their studies - for listening to lectures, by accessing books, articles or websites, or by writing papers or assignments' (Frumina \& West, 2012, p. 44).

However, the situation has changed since 2012 as at least half of NUST MISiS graduates reported using English in their jobs and see it as a competitive advantage (Table 3). More than half of bachelors are motivated by the perspective to pass IELTS exam, though the entrants mainly choose the university for other reasons.

This 50:50 proportion of those who need English for employment and who do not is due to different career paths for different majors. Thus, two college administrators explained that the main employer for engineers in Russia is military-industrial complex, where international ties are very restricted. Citing Head of CEng, 'The possibility that our graduates will need English working on a metallurgical plant somewhere in Navoi, or Novolipetsk, or Tuesunzade is very low'. At the same time, students who are planning to work in science, programming or seek employment in international companies have well-defined needs in English.

The subject disciplines respond to the challenges of internationalization of engineering education but not very fast. There are still neither formal requirements to use English sources in student's papers nor necessity for oral communication outside the English class. Subject lecturers rarely have English proficiency sufficient to give lectures or write papers in English.

The most required are receptive skills, while oral and written communication like writing research papers and making presentations is often neglected. According to our results, bachelors and masters occasionally give talks and write abstracts in English for students 'events only, and articles are written almost exclusively by scientific advisors. The situation is changing vary fast, though, with more international students coming to study at the university and more contacts establishing with scientists and engineers abroad.

In the situation where there is no clear request from industry or academic community, it seems hardly possible to design an English course which meets learners' actual needs. 
In the current situation any English course for engineers in our country will be aimed at their potential rather than real-life needs. We believe that the primary goal today is to get learners to B1/B2 level of proficiency. Having become 'independent users' (Council of Europe, 2001), students will be able to use the language flexibly and not be confined to a particular skill or context.

Secondly, although reading seems the most required skill for those $50 \%$ who use English in their careers, we cannot neglect oral and writing communication. In order to develop all language skills in a balanced manner, the orientation on international exams such as IELTS Academic Module can be the best solution. However, the impediment here might be low proficiency levels, insufficient to operate successfully in EAP environment.

IELTS materials provide the focus on academic skills, which particularly benefit those who have chosen career in research. At the same time transferable skills students acquire and develop in academic modules can be applicable to any career path (Rossikhina \& Ermakova, 2018).

The most debatable issue is integration of ESP in the syllabus as the task to cater for all majors is really challenging. As a result, at NUST MISiS subject-specific aspects are introduced only through ESP projects. The main concern of many subject professors is that students demonstrate poor knowledge of technical terms, which 'leads to inability to translate articles, listen to lectures and present results of research'. IYAKT department believes that all the problems listed above can be easily overcome if the level of language proficiency is sufficiently high. This view is supported by other academics who admit that 'students with good command of English can easily learn specialist vocabulary themselves'.

We believe that currently the English language needs of engineering students in Russia are very similar and the situation at NUST MISiS can be generalized to many other technical universities in the country. Students' actual needs can inform any EAP/ESP course syllabus, though they have to be revised regularly due to changing academic and professional landscape in Russia.

\section{References}

Arefiev, A. (2008). The international educational market and Russian universities. Vysshee obrazovanie $v$ Rossii, (2), 144-157. (In Russ.)

Artemeva, N., Logie, S., \& St. Martin, J. (1999). From page to stage: how theories of genre and situated learning help introduce engineering students to discipline-specific communication. Technical Communication Quarterly, (8), 301-316. doi: 10.1080/10572259909364670

Bell, E., \& Bryman, A. (2003). Business Research Methods. Oxford: Oxford University Press. 776 p.

Braine, G. (2002). Academic literacy and the nonnative speaker graduate student. Journal of English for Academic Purposes, 1, 59-68. doi: 10.1016/S1475-1585(02)00006-1

Council of Europe. (2001). Common European framework of references to languages: learning, teaching, assessment. Cambridge: Cambridge University Press.

Cowling, D.J. (2007). Needs analysis: planning a syllabus for a series of intensive workplace courses at a leading Japanese company. English for Specific Purposes, 26, 426-442. doi: 10.1016/j. esp.2006.10.003 
Darling, A.L., \& Dannels, D.P. (2003). Practicing engineers talk about the importance of talk: a report on the role of oral communication in the workplace. Communication Education, 52, 1-16. doi: $10.1080 / 03634520302457$

Dooey, P. (2010). Students perspectives of an EAP pathway program. Journal of English for Academic Purposes, 9, 184-197. doi: 10.1016/j.jeap.2010.02.013

Frumin, I., \& Dobryakova, M. (2012). Chto zastavlyaet menyatsa rossiyskie vusy: dogovor nevovlechennosti. Voprosy obrazovaniya, (2), 159-190. (In Russ.)

Frumina, E., \& West, R. (2012). British Council Baseline Study: Internalization of Russian Higher Education - the English Language Dimension. Available at: https:/www.britishcouncil.ru/sites/ default/files/russian_baseline_report_2012.pdf

Gotlib, R.A. (2009). Social'naya vostrebovannost znanya inostrannogo yazyka. Sociologicheskie issledovaniya, (2), 122-127. (In Russ.)

Huhta, M., Vogt, K., Johnson, E., \& Tulkki, H. (2013). Needs Analysis for Language Course Design. A Holistic Approach. Cambridge: Cambridge University Press. 266 p.

Hutchinson, T., \& Waters, A. (1997). English for Specific Purposes: a Learning-Centered Approach. Cambridge: Cambridge University Press. 183 p.

Jordan, R. (1997). English for Academic Purposes. Cambridge: Cambridge University Press. 403 p.

Kassim, H., \& Ali, F. (2010). English communication events and skills needed at the workplace: feedback from the industry. English for Specific Purposes, 29, 168-182. doi: 10.1016/j.esp.2009.10.002

Levchenko, V., Postnikova E., \& Dudovich, D. (2016). Otbor i strukturirovanie soderzhaniya vysshego obrazovaniya v kontexte internalizatsii. Modern Science: Actual Problems of Theory and Practice. Series: Humanities, (9), 60-64. (In Russ.)

Ministry of Science and Higher Education of the Russian Federation. (2018). 5-100 Russian Academic Excellence Project. Available at: https://www.5top100.ru/en

Polenova, A. \& Pschegusova, G. (2015). Foreign language as a tool for professional mobility development for students specializing in economics. Journal of Economic Regulation, 6(1), 129-136. (In Russ.)

Prior, J. (2014). Investigating the university-workplace interface: implications for English for Specific Academic Purposes instruction. Journal of the IATEFL ESP SIG, 44, 19-24.

Rossikhina, O., \& Ermakova P. (2018). The role of an English course in transferable skill acquisition. Inoyazychnoe obrazovanie v polikulturnoi srede. XXIV NATE Conference Proceedings, 108-116. Samara: Samara University Publ.

Sageev, P., \& Romanovski, C. (2001). A message from recent engineering graduates in the workplace: results of a survey on technical communication skills. Journal of Engineering Education, 90(4), 685-693. doi: 10.1002/j.2168-9830.2001.tb00660.x

Serafini, E., Lake, J., \& Long, M. (2015). Needs analysis for specialized learner populations: essential methodological improvements. English for Specific Purposes, 40, 11-26. doi: 10.1016/j. esp.2015.05.002

Sostoyanie rossiyskogo rynka truda dlya molodyrh specialistov. (2018). Available at: https://hhcdn.ru/ file/16535632.pdf

Federalnye obrazovatelnye standarty 2016-2018 [State Educational Standards for 2016-2018]. Available at: www.fgos.ru (In Russ.)

Levada Center. (2014). Center for Human Technologies: Information+Analytical Portal: 70 percent of Russians Do Not Speak Foreign Languages. Available at: http://gtmarket.ru/news/2014/05/28/6787 (In Russ.) 
Article history:

Received: 03 February 2019

Revised: 19 February 2019

Accepted: 20 February 2019

For citation:

Rossikhina, O.G., Ermakova, P.V., \& Aleshchenko, O.A. (2019). Analysis of the English Language Needs of Students at the Russian Technological University. RUDN Journal of Psychology and Pedagogics, 16(1), 88-100. http://dx.doi.org/10.22363/2313-1683-2019-16-1-88-100

\title{
Bio Notes:
}

Olga G. Rossikhina - Ph.D. in Biology, Associate Professor of the Department of Modern Languages and Communication of the National University of Science and Technology MISiS (Moscow, Russia). ORCID ID: 0000-0001-7569-0139. E-mail: rossog@rambler.ru

Polina V. Ermakova - Ph.D. in Philology, Associate Professor of the Department of Modern Languages and Communication of the National University of Science and Technology MISiS (Moscow, Russia). ORCID ID: 0000-0003-3169-491. E-mail: polina.ermakova.misis@gmail.com

Olga A. Aleshchenko - Assistant Professor of the Department of Modern Languages and Communication of the National University of Science and Technology MISiS (Moscow, Russia). ORCID ID: 0000-0001-9488-2769. E-mail: olganikif@mail.ru

Исследовательская статья

\section{Анализ потребности в изучении английского языка у студентов российского технологического университета}

\author{
О.Г. Россихина, П.В. Ермакова, О.А. Алещенко \\ Национальный исследовательский технологический университет МИСиС \\ Российская Федерация, 119049, Москва, Ленинский проспект, 4
}

В статье рассматривается потребность в изучении английского языка у студентов и недавних выпускников российского инженерного вуза - НИТУ МИСиС. Авторы изучали, насколько часто и в каких ситуациях в академическом и профессиональном контексте респондентам необходимо знание английского языка. Для исследования была использована смешанная качественная и количественная методология. Были проанализированы 107 бумажных анкет студентов-магистров, статистически обработаны 123 результата онлайн-опроса выпускников университета 2015 и 2016 годов, а также проведены 17 структурированных интервью с руководителями подразделений и профессорами предметных кафедр с целью выделения основных категорий использования английского языка как инструмента общения. В результате было показано, что, несмотря на значительные успехи НИТУ МИСиС на пути интернализациации в рамках Проекта 5-100, владение английским языком все еще не является приоритетом. Большинство вчерашних выпускников «не уверено», что это помогло им в трудоустройстве, а некоторые администраторы считают эту компетенцию наименее востребованной. Тем не менее степень использования английского языка зависит от специализации студента: на- 
учные направления и программирование без этого невозможны, тогда как экономисты и многие инженерные специальности могут коммуницировать исключительно на родном языке. Авторы размышляют о том, как ориентация на потенциальные нужды студентов отражается на дизайне курсов академического и специального английского языка.

Ключевые слова: анализ потребностей, английский язык, студенты инженерных специальностей, трудоустройство, анкетирование, систематизированные интервью

\section{История статьи:}

Поступила в редакцию: 02 февраля 2019 г.

Принята к печати: 20 февраля 2019 г.

\section{Для цитирования:}

Rossikhina O.G., Ermakova P.V., Aleshchenko O.A. Analysis of the English Language Needs of Students at the Russian Technological University (Анализ потребности в изучении английского языка у студентов российского технологического университета) // Вестник Российского университета дружбы народов. Серия: Психология и педагогика. 2019. Т. 16. № 1. C. 88-100. http://dx.doi.org/10.22363/2313-1683-2019-16-1-88-100

\section{Сведения об авторах:}

Россихина Ольга Глебовна - кандидат биологических наук, доцент кафедры иностранных языков и коммуникативных технологий Национального исследовательского технологического университета МИСиС (Москва, Россия). ORCID ID: 0000-0001-7569-0139. E-mail: rossog@rambler.ru

Ермакова Полина Викторовна - кандидат филологических наук, доцент кафедры иностранных языков и коммуникативных технологий Национального исследовательского технологического университета МИСиС (Москва, Россия). ORCID ID: 0000-0003-3169491. E-mail: polina.ermakova.misis@gmail.com

Алещенко Ольга Алексеевна - старший преподаватель кафедры иностранных языков и коммуникативных технологий Национального исследовательского технологического университета МИСиС (Москва, Россия). ORCID ID: 0000-0001-9488-2769. E-mail: olganikif@mail.ru 